\title{
LEGAL HISTORIS KEWENANGAN PENGUJIAN DAN PEMBATALAN PERATURAN DAERAH SERTA IMPLIKASINYA TERHADAP KEMUDAHAN BERUSAHA
}

\author{
(Legal History of Local Regulation Review and Cancellation \\ and Implication Towards Ease of Doing Business)
}

\author{
Muhammad Reza Winata, Mery Christian Putri, dan Zaka Firma Aditya \\ Pusat Penelitian dan Pengkajian Perkara, dan Pengelolaan Perpustakaan \\ Mahkamah Konstitusi Republik Indonesia \\ Jalan Medan Merdeka Barat Nomor 6, Jakarta Pusat \\ Email:mreza.winata@gmail.com
}

Naskah diterima: 18 Agustus 2018; revisi: 8 Oktober 2018; disetujui: 29 Oktober 2018

\begin{abstract}
Abstrak
Harmonisasi Peraturan Pusat dan Peraturan Daerah (Perda) penting dilakukan untuk mendukung peningkatan kemudahan berusaha di Indonesia. Hal ini juga dipengaruhi oleh kewenangan pengujian dan pembatalan Perda yang menghambat kemudahan berusaha. Tulisan ini hendak membahas mengenai legal historis pengaturan pengujian dan pembatalan Perda, serta dampak putusan Mahkamah Konstitusi (MK) Nomor 137/PUU-XIII/2015 dan Putusan Nomor 56/PUU-XIV/2016 terhadap kemudahan berusaha di Indonesia. Metode penelitian yang digunakan dalam penelitian ini adalah yuridis normatif yang bersifat preskriptif analitis dengan pendekatan regulasi, doktrinal, dan putusan. Hasil penelitian menunjukan secara legal historis kewenangan Pemerintah Pusat menguji dan membatalkan Perda mengalami dinamika sampai akhirnya kewenangan ini ekslusif hanya dimiliki kepada Mahkamah Agung. Penghapusan kewenangan Pemerintah Pusat menguji dan membatalkan Perda yang dianggap menghambat investasi akan berimplikasi negatif terhadap kemudahan berusaha dan dapat menurunkan rangking Ease of Doing Business Indonesia.

Kata kunci: pembatalan, Peraturan Daerah, dampak, kemudahan berusaha, investasi
\end{abstract}

\begin{abstract}
Harmonization of the Central Regulations and Regional Regulations (Perda) is important to improve Ease of Doing Business (EoDB) in Indonesia. This rank is also affected by the authority to review and cancel Perda that hinder the EoDB. This paper would like to discuss the legal history of regulations for review and cancellation of Perda and then the impact of Constitutional Court (MK) Decision No. 137/PUU-XIII/2015 and Decisions No. 56/PUU-XIV/2016 on (EoDB). The research method used in this study is normative juridical which is prescriptive analytical with regulatory, doctrinal, and decision approaches. The research results show that in legal history persepctive, the authority of Central Government to review and cancel Perda has experienced dynamics until finally this authority is exclusively owned by the Supreme Court. The cancellation of Central Government authority to review and cancel Perda that are considered to hamper investment will have negative implications for EODB and can reduce Indonesia ranking.
\end{abstract}

Keywords : cancellation, Local Regulation, impact, Ease of Doing Business, investment 


\section{A. Pendahuluan}

Upaya dari rezim pemerintahan Jokowi dalam memperbaiki iklim berusaha di Indonesia terus mengalami peningkatan. Hal ini tercermin dari naiknya peringkat Indonesia terhadap kemudahan berusaha dan berinvestasi. Dalam survei World Bank bertajuk Ease of Doing Bussiness (EoDB) tahun 2018, Indonesia menempati posisi ke 72 dengan skor 66.47 sebagai negara dengan tingkat kemudahan berbisnis dari 190 negara di dunia. ${ }^{1}$ Angka ini mengalami peningkatan yang cukup signifikan sejak Presiden Jokowi menjabat sebagai kepala pemerintahan ditahun 2014, yaitu peringkat 120 (2014), peringkat 114 (2015), peringkat 106 (2016), dan peringkat 91 (2017). ${ }^{2}$
Capaian fantastis yang diperoleh Indonesia dalam Ease of Doing Bussiness ini tidak terlepas dari kebijakan Pemerintahan Jokowi yang menerapkan paket kebijakan ekonomi jilid 1 hingga jilid 16 serta kebijakan memangkas jalur birokrasi dan regulasi dengan tujuan untuk mempermudah para investor dalam menanamkan modalnya di Indonesia. Akan tetapi, peringkat Indonesia ini masih kalah jauh dibandingkan negara tetangga di Asia Tenggara, yakni Vietnam (68), Brunei Darussalam (56), Thailand (26), Malaysia (24) dan Singapura (2). Selengkapnya capaian Ease of Doing Bussiness negara di kawasan Asia Tenggara dapat dilihat dalam tabel dibawah ini:

Tabel 1. Ease of Doing Bussiness rangking $2018^{3}$

\begin{tabular}{lllllll}
\hline Negara & 2014 & 2015 & 2016 & 2017 & 2018 & Skor \\
\hline Singapura & 1 & 1 & 1 & 1 & 2 & 84.57 \\
\hline Malaysia & 6 & 18 & 18 & 23 & 24 & 78.43 \\
\hline Thailand & 18 & 26 & 49 & 46 & 26 & 77.44 \\
\hline Brunei Darussalam & 59 & 101 & 84 & 72 & 56 & 70.60 \\
\hline Vietnam & 99 & 78 & 90 & 82 & 68 & 67.93 \\
\hline Indonesia & 120 & 114 & 106 & 91 & 72 & 66.47 \\
\hline Philipina & 108 & 95 & 103 & 99 & 113 & 58.74 \\
\hline Kamboja & 137 & 135 & 127 & 131 & 135 & 54.47 \\
\hline Myanmar & - & 177 & 167 & 170 & 171 & 44.21 \\
\hline Timor Leste & 172 & 172 & 173 & 175 & 178 & 40.62 \\
\hline
\end{tabular}


Dari tabel diatas dapat dilihat bahwa untuk tingkat ASEAN saja, Indonesia masih tertinggal cukup jauh dari negara tetangga dan hanya berada di peringkat ke-6 dari 11 negara di kawasan ASEAN. Oleh karena itu, pemerintah terus berupaya meningkatkan kemudahan berusaha di Indonesia. Salah satu caranya adalah melalui penguatan peran hukum yang tidak hanya untuk memberikan fasilitas kemudahan dalam berusaha, tetapi juga memberikan perlindungan bagi persaingan usaha. Adapun regulasi yang dibangun harus mampu menyeimbangkan berbagai kepentingan tidak hanya untuk kepentingan investor saja, melainkan juga harus memperhatikan kepentingan negara dan masyarakat luas.

Permasalahan yang sering terjadi adalah banyaknya regulasi yang saling tumpang tindih satu sama lain terutama antara peraturan di tingkat pusat dengan peraturan pelaksananya sampai dengan peraturan di tingkat daerah. Apalagi, menguatnya sistem desentralisasi dan otonomi daerah menjadikan daerah memiliki kekuasaan yang cukup luas dalam menentukan produk hukum daerahnya sesuai dengan perspektif daerahnya masing-masing. Oleh sebab itu, dalam rezim pemerintahan daerah saat ini, produk hukum daerah yang subtansinya tidak sejalan dengan produk hukum pemerintahan pusat dapat dengan mudah ditemui.
Sebagai langkah preventif untuk tetap menciptakan iklim berusaha yang kondusif, berdasarkan Undang-Undang Nomor 23 Tahun 2014 tentang Pemerintahan Daerah, Pemerintah Pusat diberikan kewenangan untuk melakukan menguji dan membatalkan Peraturan Daerah (Perda) yang dianggap dapat menghambat investasi. Kewenangan tersebut diberikan kepada Menteri Dalam Negeri (Mendagri) yang dapat menguji dan membatalkan Perda Provinsi, serta Gubernur yang dapat menguji dan membatalkan Perda Kabupaten/Kota. ${ }^{4}$ Menurut data dari Kementerian Dalam Negeri (Kemendagri), dalam kurun waktu 2007 - 2015 terdapat setidaknya 1765 Perda Kabupaten/ Kota yang dicabut oleh Mendagri, dan 1267 Perda Kabupaten/Kota yang telah dibatalkan oleh Gubernur. ${ }^{5}$ Beberapa Perda yang dibatalkan tersebut adalah Perda pajak, Perda retribusi, Perda perizinan, Perda retribusi izin gangguan, Perda pengambilan dan pengelolaan galian $C$, serta Perda yang berhubungan dengan sumber daya alam dan mineral. ${ }^{6}$

Menariknya, kewenangan Mendagri dan Gubernur dalam menguji dan membatalkan Perda ini kemudian dibatalkan oleh Mahkamah Konstitusi (MK) dalam Putusan Nomor 137/

4 Pembatalan Perda dalam Undang-Undang Nomor 23 Tahun 2014 diatur dalam Pasal 251 ayat (1) dan ayat (2) yang berbunyi:

(1) Perda Provinsi dan peraturan gubernur yang bertentangan dengan ketentuan peraturan perundangundangan yang lebih tinggi, kepentingan umum, dan/atau kesusilaan dibatalkan oleh Menteri.

(2) Perda Kabupaten/Kota dan peraturan bupati/wali kota yang bertentangan dengan ketentuan peraturan perundang-undangan yang lebih tinggi, kepentingan umum, dan/atau kesusilaan dibatalkan oleh Gubernur sebagai wakil Pemerintah Pusat.

5 Kementerian Dalam Negeri Republik Indonesia, Daftar Perda/Perkada dan Peraturan Menteri Dalam Negeri yang Dibatalkan/Direvisi, 2016, hlm. 2-104.

6 Ibid. 
PUU-XIII/2015 ${ }^{7}$ dan Putusan Nomor 56/PUUXIV/2016. ${ }^{8}$ Secara umum, terdapat 5 (lima) alasan Mahkamah Konstitusi dalam mencabut kewenangan Mendagri dan Gubernur dalam membatalkan Perda, antara lain:

1. Keberadaan judicial review di dalam suatu negara hukum, merupakan salah satu syarat tegaknya negara hukum itu sendiri, sebagaimana tersurat dalam Pasal 1 ayat (3) UUD 1945. Peraturan perundang-undangan hanya layak diuji oleh suatu lembaga yustisi.

2. Menurut UU No 12 Tahun 2011 tentang Pembentukan Peraturan Perundangundangan, Perda jelas disebut sebagai salah satu bentuk peraturan perundangundangan dengan hierarki di bawah UU. Maka sebagaimana ditentukan oleh Pasal 24A ayat (1) UUD 1945, pengujiannya hanya dapat dilakukan oleh Mahkamah Agung, bukan oleh lembaga lain.

3. Eksekutif bisa membatalkan Perda menyimpangi logika dan bangunan negara hukum Indonesia sebagaimana amanah Pasal 1 ayat (3) UUD 1945 juga menegasikan peran dan fungsi Mahkamah Agung sebagai lembaga yang berwenang melakukan pengujian peraturan perundang-undangan di bawah UU in casu Perda Kabupaten/Kota sebagaimana ditegaskan dalam Pasal 24A ayat (1) UUD 1945.

4. Ekses dari produk hukum pembatalan Perda dalam lingkup eksekutif dengan produk hukum ketetapan Gubernur sebagaimana ditentukan dalam Pasal 251 ayat (4) UU Pemda berpotensi menimbulkan dualisme putusan pengadilan jika kewenangan pengujian atau pembatalan Perda terdapat pada lembaga eksekutif dan lembaga yudikatif.

5. Jika peraturan daerah itu sudah mengikat umum, maka sebaiknya yang mengujinya adalah lembaga peradilan sebagai pihak ketiga yang sama sekali tidak terlibat dalam proses pembentukan peraturan daerah yang bersangkutan sesuai dengan sistem yang dianut dan dikembangkan menurut UUD 1945 yakni "centralized model of judicial review", bukan "decentralized model", seperti ditentukan dalam Pasal 24A ayat (1) dan Pasal 24C ayat (1) UUD 1945.

Mendagri kemudian merespon Putusan MK tersebut dengan menyatakan bahwa Putusan MK menghalangi proses deregulasi terhadap Perda yang menghambat kemudahan berusaha. Logika dari pemerintah adalah bahwa pembatalan Perda yang dilakukan oleh Mendagri 
adalah salah satu langkah dalam menumbuhkan iklim berusaha di Indonesia. Perda-Perda yang dibatalkan dan direvisi adalah Perda-Perda yang secara subtansi bertentangan dengan kebijakan dan peraturan diatasnya. Untuk itu, Mendagri menganggap bahwa Putusan No. 137/PUUXIII/2015 dan Putusan No. 56/PUU-XIV/2016 justru telah menghambat investasi dan iklim berusaha di Indonesia. ${ }^{9}$

Untuk itulah, terdapat urgensi mengkaji diskursus ketatanegaraan ini dengan kebaruan gagasan dalam jurnal ini yaitu menjelaskan legal historis pengaturan kewenangan pengujian dan pembatalan peraturan daerah, serta implikasi Putusan No. 137/PUU-XIII/2015 dan Putusan No. 56/PUU-XIV/2016 terhadap kemudahan berusaha (ease of doing business) di Indonesia.

\section{B. Metode Penelitian}

Penelitian ini merupakan penelitian hukum dengan metode hukum normatif yang bersifat preskriptif. Peter Mahmud Marzuki mengatakan bahwa pendekatan dalam penelitian hukum terdiri atas pendekatan undang-undang (statue approach), pendekatan kasus (case approach), pendekatan historis (historical approach), pendekatan perbandingan (comparative approach) dan pendekatan konseptual (conceptual approach). ${ }^{10}$ Dalam penulisan ini menggunakan pendekatan undang-undang dan pendekatan konseptual.
Pendekatan konseptual (conceptual approach) ini beranjak dari pandanganpandangan dan doktrin-doktrin yang berkembang dalam ilmu hukum. Dengan mempelajari pandangan-pandangan dan doktrin-doktrin di dalam ilmu hukum, peneliti akan menemukan ide-ide yang melahirkan pengertian-pengertian hukum, konsep-konsep hukum, dan asas-asas hukum yang relevan dengan isu yang dihadapi. ${ }^{11}$ Sedangkan pendekatan perundang-undangan (statue approach) dilakukan dengan menelaah semua undang-undang dan regulasi yang bersangkut paut dengan isu hukum yang sedang dikaji. ${ }^{12}$

\section{Pembahasan}

1. Legal Historis Pengaturan Kewenangan Pengujian dan Pembatalan Peraturan Daerah dalam Konstitusi dan UndangUndang

Peraturan daerah (Perda) merupakan salah satu instrumen hukum penting dalam sistem hukum di Indonesia sebagai pelaksanaaan otonomi daerah. Dalam bingkai negara kesatuan, dibutuhkan mekanisme yang menjamin keselarasan peraturan di daerah dengan di tingkat pusat yaitu melalui pengujian dan pembatalan Perda yang dianggap bermasalah. ${ }^{13}$ Perkembangan pengaturan kewenangan pengujian dan pembatalan Perda

9 Metro TV, "Mendagri Sebut Putusan MK Hambat Investasi", http://news.metrotvnews.com/politik/1bV6ejQbmendagri-sebut-putusan-mk-hambat-investasi (diakses 15 Agustus 2018).

10 Peter Mahmud Marzuki, Penelitian Hukum (Jakarta: Kencana Media Group, 2014), hlm. 93.

$11 \quad$ Ibid., hlm.135.

12 Ibid., hlm. 133.

13 Terminologi Perda bermasalah yang dimaksud merupakan Perda yang cenderung membebani masyarakat dengan biaya tinggi dan keruwetan birokrasi, hal ini disebabkan pemerintah daerah ingin meningkatkan pendapatan daerah, namun dapat merusak iklim usaha dan berdampak negatif pada perekonomian nasional. Lihat Sutra Ningsi, "Inventarisasi dan Evaluasi Perda", bab dalam Otonomi Daerah, Etnonasionalisme, dan Masa Depan Indonesia (Jakarta: Yayasan Pusaka Obor Indonesia, 2010), hlm. 187. 
dapat ditelusuri berdasarkan legal historis ${ }^{14}$ penerapan hukumnya di Indonesia. Tulisan ini, menelaah pengaturan di tingkat konstitusi sebagai sumber legitimasi kewenangan ${ }^{15}$ dan pengaturan di tingkat undang-undang yang mengatur berkaitan dengan kewenangan tersebut. ${ }^{16}$

Sejarah mencatat, berdirinya negara konstitusional merupakan proses panjang perkembangan ketatanegaraan dalam suatu negara yang dipengaruhi perubahan dan penggantian konstitusi. ${ }^{17} \mathrm{Hal}$ ini, juga terjadi di Indonesia yang telah menerapkan konstitusi dalam beberapa periode, antara lain: UndangUndang Dasar 1945 (naskah asli); Konstitusi Republik Indonesia Serikat (Konstitusi RIS); Undang-Undang Dasar Sementara Tahun 1950 (UUDS 1950); dan Undang-Undang Dasar 1945 (amandemen). ${ }^{18}$

Dalam UUD 1945 (naskah asli), Pasal

24 mengatur bahwa Kekuasaan kehakiman dilakukan oleh sebuah Mahkamah Agung dan lain-lain badan kehakiman menurut undangundang, sedangkan susunan dan kekuasaan badan-badan kehakiman itu diatur dengan undang-undang. Dalam konstitusi pertama Indonesia ini tidak dapat ditemukan secara tegas pengaturan yang memberikan kewenangan menguji dan membatalkan Perda oleh suatu lembaga negara tertentu.

Berikutnya Pasal 113 Konstitusi RIS menyatakan bahwa Mahkamah Agung Indonesia susunan dan kekuasaannya diatur dengan undang-undang federal. Mahkamah Agung juga berkuasa menyatakan dengan tegas bahwa suatu ketentuan dalam peraturan ketatanegaraan atau dalam undang-undang daerah bagian tidak seusai Konstitusi. Terlihat dalam konstitusi ini, bahwa Indonesia secara konstitusional pertama kali mengenal mekanisme pengujian dan pembatalan Perda oleh lembaga negara tertentu yaitu Mahkamah Agung sebagai cabang kekuasaan kehakiman.

Selanjutnya dalam Pasal 78 UUDS 1950, menjelaskan bahwa susunan dan kekuasaan Mahkamah Agung diatur dengan undangundang. Dalam perubahan konstitusi Indonesia ini juga tidak dapat ditemukan norma yang

14 Legal historis merupakan analisis terhadap perkembangan aturan yang berlaku, penulis berfokus mengkaji legal historis internal yang menunjukan perubahan norma-norma dalam peraturan perundang-undangan. Lihat Philip Handler yang menjelaskan metode ini sebagai berikut,"A core aim of legal history is to provide insight into the mechanisms and dynamics of legal change. Internal legal history may be described as the history of law, but external legal history encroaches onto the political, intellectual and social realm", Philip Handler, "Legal History", bab dalamResearch Methods in Law (New York: Routledge, 2013), hlm. 22.

15 Jimly Asshidiqie menjelaskan terdapat sepuluh fungsi konstitusi, berkaitan dengan analisis legal historis kewenangan dalam konstitusi, maka fungsi yang dimaksud adalah sebagai pemberi atau sumber legitimasi terhadap kekuasaan negara ataupun kegiatan penyelenggaraan kekuasaan negara. Lihat Jimly Asshidiqie, Konstitusi dan Konstitusionalisme (Jakarta: Konstitusi Press, 2005), hlm. 27-28.

16 Undang-Undang yang mengatur mengenai kewenangan pengujian dan pembatalan Peraturan Daerah, antara lain: Undang-Undang tentang Pemerintahan Daerah; Undang-Undang tentang Pembentukan Peraturan Perundangundangan; Undang-Undang tentang Kekuasaan Kehakiman; dan Undang-Undang tentang Mahkamah Agung.

17 M. Agus Santoso, "Perkembangan Konstitusi di Indonesia", Jurnal Yustisia, Vol. 2, No. 3 September-Desember (2013): 121.

18 Jimly Asshidiqie menjelaskan terjadinya beberapa penerapan konstitusi dikarenakan setiap konstitusi merupakan produk resultante pada waktu tertentu sehingga jika situasinya berubah maka konstitusinya akan berubah kembali dengan resultante baru agar sesuai dengan perkembangan kebutuhan dan tuntutan zaman. Jimly Asshidiqie, Seminar Konstitusi "Kontroversi Amandemen UUD 1945 dan Pengaruhnya Terhadap Sistem Ketatanegaraan," makalah disampaikan pada Seminar Konstitusi, Jakarta, 12 April 2007). 
mengatur kewenangan pengujian dan pembatalan Perda dilaksanakan oleh lembaga negara tertentu.

Sedangkan dalam Pasal 24A UUD 1945 (amandemen), mengatur bahwa Mahkamah Agung berwenang mengadili pada tingkat kasasi, menguji peraturan perundangundangan di bawah undang-undang terhadap undang-undang, dan mempunyai wewenang lainnya yang diberikan oleh undangundang. Berdasarkan UU No. 12 Tahun 2011 tentang Pembentukan Peratuan Perundangundangan, ${ }^{19}$ Perda termasuk dalam hierarki peraturan perundang-undangan yang terdiri dari Peraturan Daerah Provinsi dan Peraturan Daerah Kabupaten/Kota. ${ }^{20}$

Berdasarkan uraian diatas, perkembangan pengaturan kewenangan pengujian dan pembatalan Perda dalam konstitusi yang pernah dan saat ini berlaku di Indonesia adalah sebagai berikut:
Pada tingkat undang-undang, khususnya Pasal 20 ayat (2) Undang-Undang Nomor 48 Tahun 2009 tentang Kekuasaan Kehakiman, Pasal 31 ayat (1) Undang-Undang Nomor 14 Tahun 1985 sebagaimana telah diubah dengan Undang-Undang Nomor 5 Tahun 2004 dan Undang-Undang Nomor 3 Tahun 2009 tentang Mahkamah Agung, serta Pasal 9 ayat (2) Undang-Undang Nomor 12 Tahun 2011 tentang Pembentukan Peraturan Perundang-undangan, mengatur kembali kewenangan Mahkamah Agung untuk menguji dan membatalkan Perda sebagaimana pengaturan kewenangan yang diatur dalam UUD 1945 amandemen. ${ }^{21}$

Selain lembaga peradilan (judicial review), pengujian dan pembatalan Perda juga dilaksanakan oleh Pemerintah Pusat terhadap pemerintah daerah (executive review). Hal ini merupakan implementasi dari konsepsi negara kesatuan serta hubungan pusat dengan daerah.

Tabel 2. Perbandingan Pengujian dan pembatalan Peraturan daerah

\begin{tabular}{|c|c|c|c|c|}
\hline & UUD 1945 Asli & Konstitusi RIS & UUDS 1950 & $\begin{array}{c}\text { UUD } 1945 \\
\text { Amandemen }\end{array}$ \\
\hline $\begin{array}{c}\text { Lembaga Penguji } \\
\text { Perda }\end{array}$ & Tidak diatur & Mahkamah Agung & Tidak diatur & Mahkamah Agung \\
\hline
\end{tabular}

19 Pasal 7 ayat (1) UU No. 12 tahun 2011 tentang Pembentukan Peraturan Perundang-undangan mengatur hierarki Peraturan Perundang-undangan terdiri atas: a. Undang-Undang Dasar Negara Republik Indonesia Tahun 1945; b. Ketetapan Majelis Permusyawaratan Rakyat; c. Undang-Undang/Peraturan Pemerintah Pengganti UndangUndang; d. Peraturan Pemerintah; e. Peraturan Presiden; f. Peraturan Daerah Provinsi; dan g. Peraturan Daerah Kabupaten/Kota.

20 Jimly Asshidiqie menyatakan Perda tidak termasuk pengertian allgemeine verbindende voorschriften (peraturan yang mengikat untuk umum), tetapi tetap dapat disebut sebagai peraturan tingkat daerah. Lihat Jimly Asshidiqie, Pengantar Ilmu Hukum Tata Negara Jilid I (Jakarta: Sekretariat Jenderal dan Kepaniteraan Mahkamah Konstitusi RI, 2006), hlm. 227-228.

21 Penulis tidak menguraikan legal historis Undang-Undang tentang Kekuasaan Kehakiman, Undang-Undang tentang Mahkamah Agung, dan Undang-Undang tentang Pembentukan Peraturan Perundang-undangan karena tidak terdapat perbedaan pengaturan yang signifikan terkait kewenangan pengujian Perda dengan yang diatur dalam UUD 1945 amandemen. 
Dalam analisis legal historis, pola dinamika pengaturan kewenangan pengujian Perda di Indonesia dapat ditemukan pada pengaturan undang-undang mengenai Pemerintahan Daerah semenjak era kemerdekaan sampai dengan pasca reformasi saat ini.

Pengaturan kewenangan menguji Perda secara normatif pertama kali diatur di UndangUndang Nomor 18 Tahun 1965 tentang Pokokpokok Pemerintahan Daerah dalam Pasal 80 yang menyatakan, keputusan-keputusan pemerintah daerah jikalau bertentangan dengan kepentingan umum, undang-undang, peraturan pemerintah atau peraturan daerah yang lebih tinggi tingkatannya, dipertangguhkan atau dibatalkan oleh Menteri Dalam Negeri bagi daerah tingkat I dan oleh kepala daerah setingkat lebih atas bagi lain-lain daerah. Meskipun menggunakan istilah keputusan, namun dalam penjelasan undang-undang ini menyatakan bahwa pengawasan represif yang dimaksud tersebut bukan hanya membatalkan keputusan daerah, namun juga terhadap Perda.

Selanjutnya, kewenangan pengujian Perda kembali diatur Undang-Undang Nomor 5 Tahun 1974 tentang Pokok-Pokok Pemerintahan di Daerah dalam Pasal 70 yang menyebutkan bahwa peraturan daerah dan atau keputusan kepala daerah yang bertentangan dengan kepentingan umum, peraturan perundang-undangan atau peraturan daerah tingkat atasnya ditangguhkan berlakunya atau dibatalkan oleh pejabat yang berwenang. Dalam pengaturan ini, terlihat penggunaan peristilahan produk hukum yang diuji secara lebih jelas yaitu peraturan daerah.

Kemudian dalam Undang-Undang Nomor 22 Tahun 1999 tentang Pemerintahan Daerah, tepatnya dalam Pasal 114 mengatur bahwa Pemerintah dapat membatalkan peraturan daerah dan keputusan kepala daerah yang bertentangan dengan kepentingan umum atau peraturan perundang-undangan yang lebih tinggi dan/atau peraturan perundangundangan lainnya beserta alasan-alasannya. Selanjutnya daerah yang tidak dapat menerima keputusan pembatalan, dapat mengajukan keberatan kepada Mahkamah Agung setelah mengajukannya kepada Pemerintah. Melalui pengaturan ini, mulai dikenal lembaga negara lain yang dapat menentukan keberatan dari pembatalan Perda.

Lalu dalam Undang-Undang Nomor 32 Tahun 2004 tentang Pemerintahan Daerah, ${ }^{22}$ pada Pasal 145 diatur bahwa Perda yang bertentangan dengan kepentingan umum dan/atau peraturan perundangundangan yang lebih tinggi dapat dibatalkan oleh Pemerintah melalui Peraturan Presiden, apabila provinsi/kabupaten/kota tidak dapat menerima keputusan pembatalan Perda dapat mengajukan keberatan kepada Mahkamah Agung dan jika dikabulkan maka Mahkamah Agung menyatakan Peraturan Presiden menjadi batal dan tidak mempunyai kekuatan hukum.

Berikutnya dalam Undang-Undang Nomor 23 Tahun 2014 tentang Pemerintahan Daerah

Dalam praktik, pembatalan Perda dianggap tidak sesuai dengan Undang-undang No. 32 Tahun 2004 karena menggunakan Kepmendagri untuk membatalkan, padahal seharusnya secara normatif menggunakan Peraturan Presiden. Lihat Yuri Sulistyo, Antikowati, \& Rosita Indrayati, "Pengawasan Pemerintah Terhadap Produk Hukum Daerah (Peraturan Daerah) Melalui Mekanisme Pembatalan Peraturan Daerah Berdasarkan Undang-Undang Nomor 32 Tahun 2004 Tentang Pemerintahan Daerah", Lentera Hukum, (April 2014): 10. 
(UU Pemda) yang berlaku saat ini, ${ }^{23}$ pada Pasal 251 mengatur bahwa Perda Provinsi dan peraturan Gubernur yang bertentangan dengan ketentuan peraturan perundang-undangan yang lebih tinggi, kepentingan umum, dan/atau kesusilaan dibatalkan oleh Menteri, sedangkan Perda Kabupaten/Kota dan peraturan bupati/ wali kota yang bertentangan dengan ketentuan peraturan perundangundangan yang lebih tinggi, kepentingan umum, dan/atau kesusilaan dibatalkan oleh Gubernur atau Menteri. Jika terjadi keberatan pembatalan, Bupati/ Walikota dapat mengajukan ke Menteri, sedangkan Gubernur dapat mengajukan ke Presiden.

Berdasarkan uraian diatas, perkembangan pengaturan kewenangan pengujian dan pembatalan Perda dalam undang-undang di Indonesia adalah sebagai berikut:

Tabel 3. Perbandingan Pengaturan Kewenangan Pengujian dan Pembatalan Perda

\begin{tabular}{|c|c|c|c|c|c|}
\hline & UU 18/1965 & UU 5/1974 & UU 22/1999 & UU 32/2004 & UU 23 /2014 \\
\hline $\begin{array}{l}\text { Lembaga } \\
\text { Penguji Perda } \\
\text { Provinsi }\end{array}$ & $\begin{array}{l}\text { Menteri Dalam } \\
\text { Negeri }\end{array}$ & $\begin{array}{l}\text { Menteri } \\
\text { Dalam Negeri }\end{array}$ & Pemerintah & Pemerintah & $\begin{array}{l}\text { Menteri Dalam } \\
\text { Negeri }\end{array}$ \\
\hline $\begin{array}{l}\text { Lembaga } \\
\text { Penguji Perda } \\
\text { Kabupaten } \\
\text { /Kota }\end{array}$ & $\begin{array}{l}\text { Kepala Daerah } \\
\text { Tingkat Atasnya }\end{array}$ & $\begin{array}{l}\text { Gubernur } \\
\text { / Menteri } \\
\text { Dalam Negeri }\end{array}$ & Pemerintah & Pemerintah & $\begin{array}{l}\text { Gubernur / } \\
\text { Menteri Dalam } \\
\text { Negeri }\end{array}$ \\
\hline $\begin{array}{l}\text { Lembaga } \\
\text { Penguji } \\
\text { Keberatan } \\
\text { Pembatalan } \\
\text { Perda }\end{array}$ & - & - & $\begin{array}{l}\text { Mahkamah } \\
\text { Agung setelah } \\
\text { mengajukan ke } \\
\text { Pemerintah }\end{array}$ & $\begin{array}{l}\text { Mahkamah } \\
\text { Agung }\end{array}$ & $\begin{array}{l}\text { Gubernur } \\
\text { ke Presiden, } \\
\text { Bupati/ } \\
\text { Walikota ke } \\
\text { Menteri Dalam } \\
\text { Negeri }\end{array}$ \\
\hline $\begin{array}{l}\text { Alasan } \\
\text { pembatalan }\end{array}$ & $\begin{array}{l}\text { - Kepentingan } \\
\text { umum } \\
\text { - Undang-undang, } \\
\text { - Peraturan } \\
\text { Pemerintah } \\
\text { - Peraturan } \\
\text { Daerah yang } \\
\text { lebih tinggi } \\
\text { tingkatan-nya }\end{array}$ & $\begin{array}{l}\text { - Kepenting- } \\
\text { an umum } \\
\text { - Peraturan } \\
\text { perundang- } \\
\text { undangan } \\
\text { - Peraturan } \\
\text { Daerah } \\
\text { tingkat } \\
\text { atasnya }\end{array}$ & $\begin{array}{l}\text { - Kepentingan } \\
\text { umum } \\
\text { - Peraturan } \\
\text { perundang- } \\
\text { undangan yang } \\
\text { lebih tinggi } \\
\text { - Peraturan } \\
\text { perundang- } \\
\text { undangan lainnya }\end{array}$ & $\begin{array}{l}\text { - Kepentingan } \\
\text { umum } \\
\text { - Peraturan } \\
\text { perundang- } \\
\text { undangan } \\
\text { yang lebih } \\
\text { tinggi }\end{array}$ & $\begin{array}{l}\text { - Perundang- } \\
\text { undangan } \\
\text { lebih tinggi } \\
\text { - Kepentingan } \\
\text { umum } \\
\text { - Kesusilaan }\end{array}$ \\
\hline
\end{tabular}

23 Meskipun dalam proses pembentukan produk hukum daerah dalam hal ini Peraturan Daerah telah diberikan pedoman berupa fasilitasi dan evaluasi, masih terdapat Peraturan Daerah yang dibatal karena adanya asas keberlakuan hukum. Lihat Angreime Igir, "Pembatalan Terhadap Peraturan Daerah Menurut Undang-Undang Nomor 23 Tahun 2014", Lex Privatum Vol. V/No. 3 (Mei 2017): 65. 
Setelah mengulas pengaturan kewenangan pengujian dan pembatalan Perda dalam Konstitusi dan Undang-Undang tentang Pemerintahan Daerah, selanjutnya akan diuraikan Putusan Mahkamah Konstitusi No. 137/PUU-XIII/2015 dan No. 56/PUU-XIV/2016 yang memberikan pembaruan pengaturan mengenai kewenangan tersebut.

Putusan Mahkamah Konstitusi No. 137/PUUXIII/2015 dalam amar putusannya menyatakan mengabulkan sepanjang pengujian Pasal 251 ayat (2), ayat (3), dan ayat (8) serta ayat (4) Nomor 23 Tahun 2014 tentang Pemerintahan Daerah Undang-Undang sepanjang frasa "...pembatalan Perda Kabupaten/Kota dan peraturan bupati/ wali kota sebagaimana dimaksud pada ayat (2) ditetapkan dengan keputusan Gubernur sebagai wakil Pemerintah Pusat", serta menyatakan frasa "Perda Kabupaten/Kota dan" dalam Pasal 251 ayat (2) dan ayat (4), frasa "Perda Kabupaten/Kota dan/atau" dalam Pasal 251 ayat (3), dan frasa "penyelenggara Pemerintah Daerah kabupaten/kota tidak dapat menerima keputusan pembatalan Perda Kabupaten/ Kota dan" dan frasa "Perda Kabupaten/Kota atau" dalam Pasal 251 ayat (8)bertentangan dengan Undang-Undang Dasar Negara Republik Indonesia Tahun 1945 dan tidak mempunyai kekuatan hukum mengikat Undang-Undang.

Hakim Konstitusi memberikan argumentasi mengabulkan, antara lain dengan menyatakan: Pertama, pemberian kewenangan kepada Menteri dan Gubernur membatalkan Perda kabupaten/kota dianggap tidak sejalan dengan prinsip Negara hukum. Kedua, menegaskan MA sebagai lembaga yang berwenang melakukan pengujian peraturan di bawah undang-undang.
Ketiga, penilaian kepentingan umum dan/atau kesusilaan yang menjadi tolok ukur menilai Perda juga merupakan kewenangan kekuasaan yudikatif. Keempat, pembatalan Perda kabupaten/kota dengan Keputusan Gubernur juga dinilai tidak tepat karena tidak sesuai dengan rezim peraturan perundang-undangan di Indonesia yang tidak mengenal keputusan gubernur dalam jenis dan hierarki peraturan perundang-undangan, MK menilai hal ini bisa mengakibatkan adanya dualisme putusan pengadilan. ${ }^{24}$

Akan tetapi, terdapat beberapa Hakim Konstitusi yang menyatakan pendapat berbeda (dissenting opinion) dengan mendalilkan Pertama, Indonesia menganut sistem satu kesatuan hukum antara pusat dan daerah. Kedua, kewenangan membentuk Perda merupakan bentuk kewenangan atribusi. Ketiga, Presiden sebagai penanggung jawab tertinggi pemerintahan mempunyai kewenangan mengambil tindakan terhadap produk hukum penyelenggara pemerintahan yang mengandung cacat. Keempat, Presiden berkepentingan memastikan penyelenggaraan pemerintahan di bawah tanggung jawabnya tidak bertentangan dengan peraturan perundang-undangan, kepentingan umum dan kesusilaan. Kelima, materi muatan Perda adalah materi yang bersubstansikan urusan Pemerintahan. Keenam, pembatalan Perda merupakan bagian dari kekuasaan eksekutif dan tidak dimaksudkan menggantikan kewenangan judicial review. Pihak yang merasa dirugikan masih dapat mengajukan judicial review. ${ }^{25}$

Apabila dikaji berdasarkan metode penafsiran konstitusi, maka akan ditemukan

4 Putusan Mahkamah No. 137/PUU-XIII/2015, hlm. 202-207.

25 Putusan Mahkamah No. 137/PUU-XIII/2015, hlm. 212-217. 
interpretasi yang digunakan oleh Hakim Konstitusi dalam memberikan putusan tersebut. Untuk 5 (lima) Hakim Konstitusi yang mengabulkan permohonan terlihat menggunakan metode interpretasi gramatikal, yaitu dengan memaknai konstitusi menurut bahasa, susunan kata atau bunyinya. ${ }^{26}$ Berdasarkan penafsiran ini ketika UUD 1945 hanya memberikan kewenangan pengujian dan pembatalan Perda kepada Mahkamah Agung (MA), maka hanya MA yang berhak melakukannya. Sedangkan untuk 4 (empat) Hakim Konstitusi yang menolak permohonan menunjukan penggunaan penafsiran penafsiran tekstual, yaitu pemaknaan yang menekankan pada pengertian atau pemahaman terhadap kata-kata yang tertera dalam konstitusi ${ }^{27}$ dan penafsiran doktrinal, yaitu memahami konstitusi melalui preseden atau melalui praktik peradilan. ${ }^{28}$ Berdasarkan penafsiran ini Hakim Konstitusi mengkonstruksikan pemaknaan dari doktrin Negara Kesatuan yang seharusnya tetap memberikan ruang kepada Pemerintah Pusat untuk dapat mengawasi Perda, meskipun kewenangan tersebut tidak diatur secara gramatikal di konstitusi.

Selanjutnya dalam Putusan Mahkamah Konstitusi No. 56/PUU-XIV/2016 dalam amar putusannya menyatakan menyatakan frasa "Perda Provinsi dan" dalam Pasal 251 ayat (1) dan ayat (4), dan frasa "Perda Provinsi dan" dalam Pasal 251 ayat (7), serta Pasal 251 ayat
(5) Undang-Undang Nomor 23 Tahun 2014 tentang Pemerintahan Daerah bertentangan dengan Undang-Undang Dasar Negara Republik Indonesia Tahun 1945 dan tidak mempunyai kekuatan hukum mengikat. Putusan ini memiliki karakteristik yang sama dengan Putusan No. 137/PUU-XIII/2015, sehingga Hakim Konstitusi dalam amar putusannya menyatakan mengikuti argumentasi hukum dalam putusan sebelumnya. ${ }^{29}$

Beberapa kelompok masyarakat merespon Putusan MK ini dengan menyatakan bahwa putusan ini mengakhiri perdebatan panjang dalam menentukan lembaga mana yang paling berhak membatalkan Perda karena berdasarkan rezim perundang-undangan lebih melihat Perda sebagai produk legislatif sehingga pengujiannya harus ditempuh melalui judicial review, sedangkan berdasarkan rezim Pemerintahan Daerah melihat Perda sebagai produk hukum yang dibentuk oleh pemerintahan daerah sehingga pembatalan dapat melalui excecutive review. ${ }^{30}$ Perbedaan pemaknaan rezim ini yang dapat dikatakan menjadi dasar argumentasi memberikan kewenangan pengujian dan pembatalan Perda.

Terdapat pandangan yang menekankan, seharusnya dalam negara dengan bentuk kesatuan memang sudah sepatutnya pemerintah yang tingkatannya lebih tinggi diberikan kewenangan untuk melakukan pengawasan terhadap Peraturan Daerah Provinsi, Kabupaten,

\footnotetext{
26 Tim Penyusun Hukum Acara Mahkamah Konstitusi, Hukum Acara Mahkamah Konstitusi (Jakarta: Sekretariat Jenderal dan Kepaniteraan Mahkamah Konstitusi RI, 2010), hlm. 70.

27 Ibid., hlm. 74.

28 Ibid., hlm. 75.

29 Putusan Mahkamah Konstitusi No. 56/PUU-XIV/2016, hlm. 97-99.

30 M. Nur Sholikin, "Penghapusan Kewenangan Pemerintah untuk Membatalkan Perda; Momentum Mengefektifkan Pengawasan Preventif Dan Pelaksanaan Hak Uji Materiil Mahkamah Agung", Jurnal RechtVinding Online, (12 Mei 2017), http://rechtsvinding.bphn.go.id/jurnal_online/Putusan\%20PUU\%20Pembatalan\%20Perda.pdf (diakses 15 Agustus 2018).
} 
dan Kota yang lahir di daerah. ${ }^{31}$ Selain itu, meskipun UUD 1945 mengatur mekanisme pengujian Perda melalui judicial review oleh Mahkamah Agung, hal itu tidak serta merta menegasikan bahwa fungsi kontrol Pemerintah Pusat terhadap Perda karena Pemerintah Pusat sebagai pemegang kekuasaan pemerintahan juga sebagai pembina dan pengawas daerah tetap memiliki andil dalam pengawasan Perda dalam formulasi yang proporsional. ${ }^{32}$

Dampak Putusan MK mengenai pembatalan Perda ini, juga akan mempengaruhi hubungan Pemerintah Pusat dengan Pemerintah Daerah khususnya keselarasan peraturan dan kebijakan. Meskipun daerah dapat dikatakan merupakan simbol diversity (perbedaan), namun seharusnya daerah tetap menjadi avant garde (garda terdepan) persatuan bangsa agar tercipta keselarasan relasi yang memusat sekaligus mendaerah melalui peraturan. ${ }^{33}$ Selain itu, Putusan MK berpotensi meningkatkan permohonan Hak Uji Materi di MA, serta menghilangkan pengawasan serta penyelarasan pembangunan daerah, putusan tersebut juga tidak memperhatikan keberadaan pasal lain yang terdampak sehingga menghilangkan daya guna pasal-pasal dalam undang-undang tentang Pemerintahan Daerah. ${ }^{34}$ Catatancatatan ini menunjukan bahwa masih terdapat permasalahan dari putusan Mahkamah Konstitusi yang menghilangkan kewenangan pengujian dan pembatalan Perda oleh Pemerintah Pusat.

Berdasarkan analisis legal historis pengaturan kewenangan pengujian dan pembatalan Perda, ditemukan bahwa terjadi perkembangan yang signifikan mulai semenjak Indonesia merdeka sampai saat ini di tingkat konstitusi maupun Undang-undang. Pada level konstitusi, MA ternyata telah diberikan kewenangan untuk menguji Perda semenjak Konstitusi RIS dan diatur kembali ketika UUD 1945 amandemen, namun tidak dtemukan secara tegas kewenangan Pemerintah Pusat untuk menguji dan membatalkan Perda dalam tingkat konstitusi.

Pada jenjang undang-undang, kewenangan MA itu ditegaskan kembali pengaturannya dalam Undang-Undang tentang Kekuasaan Kehakiman, Undang-Undang tentang Mahkamah Agung, dan Undang-Undang tentang Pembentukan Peraturan Perundang-undangan. Sedangkan kekuasaan Pemerintah Pusat menguji dan membatalkan Perda telah mengalami dinamika kewenangan mulai semenjak undang-undang mengenai Pemerintah Daerah yang pertama kali berlaku sampai dengan Putusan Mahkamah Konstitusi yang mempengaruhi Undangundang mengenai Pemerintah Daerah saat ini. Putusan tersebut, menghapuskan kewenangan Pemerintah Pusat yang telah berlaku dalam sistem hukum Indonesia selama 50 tahun.

31 Eka NAM Sihombing, "Perkembangan Kewenangan Pembatalan Peraturan Daerah dan Peraturan Kepala Daerah", Jurnal Yudisial, Vol. 10, No. 2 (Agustus 2017): 232.

32 Imam M. Nasef dalam Fathorrahman, "Telaah Hukum Tentang Pembatalan Peraturan Daerah (Perda) oleh Pemerintah Pasca Putusan Mahkamah Konstitusi Nomor : 56/PUU-XIV/2016", Jurnal Rechtens, Vol. 6, No. 1 (Juni 2017): 71.

33 I Gde Pantja Astawa, Problematika Hukum Otonomi Daerah di Indonesia (Bandung: PT. Alumni, 2009), hlm. 72-73.

34 Muhammad Amin Putra, "Masalah Pembatalan Perda oleh Mahkamah Konstitusi", Kolom Hukum Online, http://www.hukumonline.com/berita/baca/lt58fd70f334428/masalah-pembatalan-Perda-oleh-mahkamahkonstitusi-oleh--muhammad-amin-putra (diakses 13 Agustus 2018). 
Tentunya Putusan tersebut berimplikasi terhadap hubungan Pemerintah Pusat dan Daerah khususnya dalam mengharmonisasi peraturan di tingkat pusat dan daerah.

\section{Implikasi Perkembangan Kewenangan Pengujian dan Pembatalan Peraturan Daerah terhadap Kemudahan Berusaha (Ease of Doing Business)}

Ease of Doing Business (EoDB) atau kemudahan dalam berusaha merupakan sebuah indeks yang mengukur sejauh mana regulasi dapat mempengaruhi 11 aspek dalam kemudahan berusaha. Indeks kemudahan berusaha (EoDB) ini awalnya diciptakan oleh Simeon Djankov di World Bank Group. Sebuah riset akademis dilaksanakan bersama-sama dengan Prof Oliver dan AndreiShleifer. ${ }^{35}$ Di dalam rangking EODB ini, Peringkat yang lebih tinggi (nilai yang kecil) mengindikasikan nilai terbaik, biasanya terwujud dalam regulasi yang lebih mudah dalam hal usaha serta perlindungan hak cipta yang lebih kuat. Riset empiris yang didanai Bank Dunia menjadi justifikasi yang menunjukan bahwa pertumbuhan ekonomi akan meningkat tajam sebagai dampak peningkatan regulasi terkait. ${ }^{36}$

Laporan kemudahan berusaha pertama kali diinisasi oleh Simeon Djankov dengan bekerjasama dengan World Bank Group pada 2003 dan dipublikasikan setiap tahun dengantujuan untuk mengukur kemudahan berinvestasi di 190 negara. Studi tentang Doing Business ini telah menjadi acuan dari World Bank Group dalam aspek pengembangan sektor publik dan diklaim dapat mendukung desain reformasi regulasi di negara-negara berkembang. Penelitian tentang EoDB ini dapat menunjukan analisis detail tentang biaya, syarat dan prosedur yang spesifik dari pendaftaran usaha / investasi sektor swasta yang disyaratkan di semua negara dan kemudian diciptakan peringkat dari setiap negara. Selain itu juga dapat mendukung upaya komunikasi yang luas, dan dengan penciptaan peringkat, hasil studi akan menampilkan negara dan pemimpin yang melaksanakan reformasi regulasi di bidang kemudahan berusaha. ${ }^{37}$

Setidaknya terdapat 10 (sepuluh) indikator yang menjadi dasar penilaian EoDB, yaitu :

a. Memulai Usaha / Starting Business

b. Perizinan Terkait Pendirian Bangunan / Dealing With Construction Permit

c. Pembayaran Pajak / Tax Payment

d. Pendaftaran Properti / Registering Property

e. Akses Perkreditan / Getting Loan

f. Penegakan Kontrak / Enforcing Contract

g. Ketersediaan Listrik / Getting Electricity

h. Perdagangan Lintas Negara / Trading Across Borders

i. Penyelesaian Perkara Kepailitan / Resolving Insolvency

j. Perlindungan Terhadap Investor / Protecting Minority Investors

Indonesia sebagai Negara berkembang secara perlahan mengalami kenaikan peringkat EoDB sejak tahun 2015. EoDB Report tahun 2016 yang bertema Measuring Regulatory and Quality and Efficiency, Indonesia mencapai posisi 106, pada tahun 2017 Indonesia masuk peringkat 91 dan di tahun 2018 ini Indonesia

\footnotetext{
35 World Bank, Loc. Cit.

36 Ibid.

37 World Bank: ’Doing Business 2010”, World Bank Group, 2010, hlm. 15.
} 
masuk peringkat 72. Pada indikator starting a business, Indonesia dinilai sebagai negara dengan prosedur yang cukup banyak dan biaya yang cukup tnggi. Seperti yang dirilis oleh Bank Dunia pada awal tahun 2016, Indonesia di peringkat 173, karena harus melewati 13 prosedur dengan waktu 46 hari dan biaya yang besar, Malaysia di peringkat 14, karena cukup dengan 3 prosedur dan waktu selama 4 hari." Sementara Singapura ada di peringkat 10. Prosedurnya sama dengan Malaysia, namun lebih singkat, karena cukup selama 2 hari. ${ }^{38}$ Indonesia masuk ke peringkat 72 dalam Doing Business Report tahun 2018 dari 192 negara yang disurvey, hal ini menunjukan kenaikan 19 peringkat dibandingkan dengan posisi Indonesia pada Doing Business Report 2017.

Pada EoDB Report 2017 yang bertema Equal Opportunity for All, Indonesia telah berhasil melaksanakan 7 dari indikator penilaian kemudahan berusaha. ${ }^{39}$ Adapun 7 perbaikan tersebut adalah :

a. Modal minimum disetor sesuai kesepakatan para pihak;

b. Mengurangi waktu dan biaya untuk mendapatkan sambungan listrik;

c. Digitalisasi data kadastral dan pemanfaatan sistem GIS;

d. Mempermudah akses perkreditan melalui pendaftaran agunan modern;

e. Pembayaran pajak secara online;

f. Mempermudah ekspor dan impor melalui peningkatan kepabeanan dan pengajuan dokumen (PEB dan PIB); g. Adanya prosedur gugatan sederhana di pengadilan niaga.

Sementara itu, pada EoDB Report 2018 dengan tema Reforming to Create Jobs, Indonesia mengalami perbaikan pada aspek berikut : ${ }^{40}$

a. Mengurangi biaya pendaftaran badan usaha sehingga memulai usaha semakin berbiaya rendah dan mudah;

b. Mengurangi koneksi dan biaya sertifikasi kabel, sehingga peroleh listrik lebih mudah dan murah;

c. Pendaftaran tanah dan hak atas tanah menjadi lebih murah dengan adanya pengurangan biaya pajak peralihan hak;

d. Meningkatkan akses ke informasi pinjaman dana melalui UMKM;

e. Memberikan perlindungan kepada investor dengan meningkatkan hak pemegang saham dan mensyaratkan keterbukaan dan transparasi korporasi;

f. Mengurangi pajak penghasilan dari 5 \% menjadi $2.5 \%$ serta memudahkan pembayaran pajak dengan adanya pendaftaran dan pendataan pajak secara online;

g. Memudahkan impor dan Perdagangan antar negara dengan memperkenalkan electronic single billing system.

Pemerintah menargetkan Indonesia dapat mencapai rangking 40 dalam Ease of Doing Business Report 2019, dan untuk membuktikan keseriusan pemerintah untuk meningkatkan

38 James Sinaga, "Upaya Pemerintah dalam Merealisasikan Kemudahan Berusaha di Indonesia, Jurnal Rechtsvinding", Vol. 6 No. 3, (2007) : 331.

39 BKPM, Perbaikan Pelaksanaan Kemudahan Berusaha Ease of Doing Business di Indonesia, https://www.bkpm. go.id/images/uploads/whyinvest_file/Greenlab_BKPM_Web_2017_Materi_Download-EoDB_Ind_20171110.pdf (diakses 7 Agustus 2018).

40 International Bank for Reconstruction and Development / The World Bank , Doing Business Report 2018 Reforming to Create Jobs, hlm. 132. 
iklim investasi di Indonesia dibentuk pula satgas (satuan tugas) khusus di bawah koordinasi Kementerian Koordinator Bidang Perekonomian. ${ }^{41}$ Tidaklah sulit mencapai rangking EoDB sesuai target, mengingat pemerintah telah menerbitkan berbagai regulasi di bidang investasi dan ekonomi bisnis secara komprehensif yang mendukung peningkatan investasi di tingkat pusat. Permasalahannya adalah bagaimana peran daerah dalam mencapai target tersebut.

Indonesia memiliki banyak daerah yang sangat potensial terhadap pendirian usaha baru atau penanaman investasi, namun seringkali tidak dapat dipungkiri peraturan daerah menghambat kemudahan berusaha dikarenakan Perda mengatur persyaratan yang lebih rigid dan ketat untuk melakukan kegiatan usaha. Untuk itu, Pemerintah melalui UU Pemda mencoba membatasi kebebasan Pemda dalam membuat Perda dengan membatalkan Perda-Perda yang dianggap dapat berpotensi menghambat kemudahan berusaha dan menghambat iklim investasi. Namun, sebagaimana telah dijelaskan dalam pembahasan pada bagian sebelumnya, putusan MK Putusan No. 137/PUU-XIII/2015 dan Putusan No. 56/PUU-XIV/2016 telah mencabut kewenangan Kemendagri melakukan pembatalan Perda Provinsi dan Kabupaten/ Kota, sehingga Pemerintah tidak lagi memiliki kewenangan mengawasi secara represif terbitnya Perda yang telah ada.

Dalam praktik, berdasarkan data yang dirilis oleh Kemendagri, terdapat 3.143 Perda yang dibatalkan oleh Pemerintah pada tahun 2016 melalui mekanisme executive review baik oleh Gubernur maupun oleh Kemendagri dengan berbagai alasan, salah satu alasan yang paling dominan dikarenakan menghambat kemudahan berusaha. ${ }^{42}$ Banyaknya terjadi pengujian dan pembatalan Perda oleh Pemerintah Pusat berdasarkan data ini, menunjukkan fakta bahwa memang banyak terjadi Perda yang menghambat kemudahan berusaha di Indonesia. Untuk itu, penghapusan kewenangan pengujian dan pembatalan Perda oleh Pemerintah Pusat, tentunya akan berdampak terhadap pengawasan Pemerintah Pusat terhadap Perda-Perda yang bersubstansikan norma yang menghambat kemudahan berusaha.

Jawa Timur merupakan daerah dengan jumlah Perda terbanyak yang dibatalkan melalui mekanisme executive review tersebut. Banyaknya Perda yang dibatalkan di Jawa Timur pada saat itu, salah satunya disebabkan oleh adanya kekhawatiran terhambatnya investasi karena beberapa Perda yang dibatalkan tidak sejalan dengan peraturan perundang-undangan di atasnya serta tidak mendukung program pemerintah dalam deregulasi pengaturan investasi untuk meningkatkan investasi. Dalam hal ini, Kemendagri sebagai perpanjangan tangan pemerintah pusat cenderung menggunakan penafsiran secara politis terhadap hukum (political intepretation on law) dalam

41 CNBC Indonesia, Jokowi dan Obsesinya pada Ease of Doing Business, https://www.cnbcindonesia.com/ news/20180125174422-4-2526/jokowi-dan-obsesinya-pada-ease-of-doing-business, (diakses pada 8 Agustus 2018)

42 Kementerian Dalam Negeri, Daftar Perda/ Perkada dan Peraturan Menteri Dalam Negeri yang Dibatalkan/ Direvisi, 2016. 
menentukan suatu peraturan daerah tersebut bertentangan dengan norma yang lebih tinggi. ${ }^{42}$

Namun tidak dapat dipungkiri, sebagai ekses dari otonomi daerah, setiap daerah seringkali merasa memiliki hak untuk membatasi tangan eksternal (investor dalam negeri dan asing) dalam pengelolaan sumber daya maupun daerahnya dengan cara menyusun Perda yang cenderung memberatkan syarat-syarat berusaha. Dari 10 (sepuluh) indikator penilaian EoDB, setidaknya 4 (empat) diantaranya menjadi kewenangan daerah untuk menentukan aturan di daerahnya sendiri yaitu melalui regulasi mengenai starting business, perizinan pendirian bangunan, pendaftaran properti, dan jumlah serta metode pembayaran pajak. Hal ini menunjukan Pemda memiliki kewenangan untuk menyusun Perda yang benar-benar dapat menghambat kemudahan berusaha.

Perlu diingat juga bahwa standar dan indikator kemudahan berusaha pada setiap rezim Pemerintah Pusat yang berkuasa akan mengalami perubahan dan perkembangan, mungkin saja di era Pemerintah Pusat sebelumnya Pemerintah Pusat meloloskan izin pembentukan Perda, namun diera Pemerintahan Pusat selanjutnya menganggap bahwa Pemda tersebut secara nyata menghambat kemudahan berusaha dan iklim investasi di daerah. Untuk itu, hilangnya kewenangan Pemerintah Pusat mengharmonisasi peraturan di tingkat pusat dengan peraturan di tingkat daerah melalui pengujian dan pembatalan Perda dapat berdampak signifikan terhadap kemudahan kegiatan berusaha di daerah.
Implikasi dari hilangnya kewenangan Pemerintah Pusat mengawasi kewenangan Pemda dalam membuat Perda yang dapat menghambat kemudahan berusaha dikarenakan Putusan No. 137/PUU-XIII/2015 dan Putusan No. 56/PUU-XIV/2016, telah mendapat keluhan dari beberapa pengusaha dan investor, terutama terkait lamanya proses penerbitan izin dan dinamika perubahan regulasi di tingkat daerah. ${ }^{43}$ Untuk itu, perubahan kewenangan pengujian dan pembatalan Perda ini, secara nyata akan dapat mempengaruhi rangking EoDB Indonesia, karena dikhawatirkan kedepannya masih terdapat Pemda yang menerbitkan Perda yang tidak sejalan dengan program pemerintah pusat dalam hal kemudahan berusaha dan menjaga iklim investasi.

\section{Penutup}

Legal historis pengaturan kewenangan pengujian dan pembatalan Perda menunjukan perkembangan signifikan mulai semenjak Indonesia merdeka sampai saat ini di tingkat konstitusi maupun Undang-undang. Pada tingkat konstitusi, Mahkamah Agung telah diberikan kewenangan tersebut dan diatur kembali ketika amandemen UUD 1945. Sedangkan pada jenjang undang-undang, kewenangan MA itu ditegaskan kembali pengaturannya dalam Undang-Undang tentang Kekuasaan Kehakiman, Undang-Undang tentang Mahkamah Agung, dan Undang-Undang tentang Pembentukan Peraturan Perundang-undangan. Akan tetapi, kewenangan Pemerintah Pusat menguji dan 
membatalkan Perda telah mengalami dinamika kewenangan mulai semenjak undang-undang mengenai Pemerintah Daerah yang pertama kali berlaku sampai dengan Putusan Mahkamah Konstitusi No. 137/PUU-XIII/2015 dan No. 56/ PUU-XIV/2016 yang memberikan kewenangan pengujian dan pembatalan Perda secara ekslusif hanya kepada Mahkamah Agung, sehingga Pemerintah Pusat tidak dapat lagi mengawasi secara langsung Perda yang bermasalah.

Perkembangan kewenangan pengujian dan pembatalan Perda yang menghilangkan kewenangan Pemerintah Pusat dapat berimplikasi negatif terhadap rangking EoDB Indonesia, karena setidaknya 4 dari 10 indikator penilaian EoDB yaitu regulasi mengenai starting business, perizinan pendirian bangunan, pendaftaran properti, dan jumlah serta metode pembayaran pajak merupakan kewenangan Pemerintah Daerah. Ketika ditemukan Perda yang dianggap tidak sesuai atau bertentangan dengan peraturan perundang-undangan di atasnya khususnya meningkatkan kemudahan berusaha, maka Pemerintah Pusat tidak memiliki kewenangan langsung untuk menguji dan membatalkan Perda bermasalah tersebut. Hal ini tentu akan berimplikasi terhambatnya agenda deregulasi Perda yang dianggap menghambat kemudahan berusaha oleh Pemerintah Pusat, sehingga juga dapat berdampak terjadinya penurunan rangking Ease of Doing Business Indonesia.

\section{Daftar Pustaka}

\section{Buku}

Asshidiqie, Jimly. Konstitusi dan Konstitusionalisme (Jakarta: Konstitusi Press, 2005).

Asshidiqie, Jimly. Pengantar IImu Hukum Tata Negara Jilid I (Jakarta: Sekretariat Jenderal dan Kepaniteraan Mahkamah Konstitusi RI, 2006).
Astawa, I Gde Pantja. Problematika Hukum Otonomi Daerah di Indonesia (Bandung: PT. Alumni, 2009).

Handler, Philip. Legal History, Research Methods in Law (New York: Routledge, 2013).

International Bank for Reconstruction and Development/The World Bank. Doing Business 2018: Reforming to Create Jobs, A World Bank Group Flagship Report (Washington: International Bank for Reconstruction and Development/The World Bank, 2018).

Kementerian Dalam Negeri Republik Indonesia. Daftar Perda/Perkada dan Peraturan Menteri Dalam Negeri yang Dibatalkan/Direvisi, (2016).

Marzuki, Peter Mahmud. Penelitian Hukum (Jakarta: Kencana Media Group, 2014).

Ningsi, Sutra. Inventarisasi dan Evaluasi Perda Otonomi Daerah, Etnonasionalisme, dan Masa Depan Indonesia (Jakarta: Yayasan Pusaka Obor Indonesia, 2010).

Tim Penyusun Hukum Acara Mahkamah Konstitusi. Hukum Acara Mahkamah Konstitusi (Jakarta: Sekretariat Jenderal dan Kepaniteraan Mahkamah Konstitusi RI, 2010).

\section{Makalah/Artikel/Prosiding/Hasil Penelitian}

Asshidiqie, Jimly. Seminar Konstitusi "Kontroversi Amandemen UUD 1945 dan Pengaruhnya Terhadap Sistem Ketatanegaraan," makalah disampaikan pada Seminar Konstitusi, Jakarta, 12 April 2007).

Igir, Angreime. "Pembatalan Terhadap Peraturan Daerah Menurut Undang-Undang Nomor 23 Tahun 2014", Lex Privatum Vol. V/No. 3 (Mei 2017).

Fathorrahman. "Telaah Hukum Tentang Pembatalan Peraturan Daerah (Perda) oleh Pemerintah Pasca Putusan Mahkamah Konstitusi Nomor : 56/PUU-XIV/2016", Jurnal Rechtens, Vol. 6, No. 1 (Juni 2017).

Santoso, M. Agus. "Perkembangan Konstitusi di Indonesia", Jurnal Yustisia, Vol. 2, No. 3 September-Desember (2013).

Sinaga, Edward James. "Upaya Pemerintah dalam Merealisasikan Kemudahan Berusaha di Indonesia", Jurnal Rechtsvending, Vol. 6 No. 3, Desember (2017).

Sihombing, Eka NAM. "Perkembangan Kewenangan Pembatalan Peraturan Daerah dan Peraturan Kepala Daerah", Jurnal Yudisial, Vol. 10, No. 2 (Agustus 2017). 
Sulistyo, Yuri,Antikowati, \& Rosita Indrayati. "Pengawasan Pemerintah Terhadap Produk Hukum Daerah (Peraturan Daerah) Melalui Mekanisme Pembatalan Peraturan Daerah Berdasarkan Undang-Undang Nomor 32 Tahun 2004 Tentang Pemerintahan Daerah", Lentera Hukum (April 2014).

James Sinaga, Upaya Pemerintah dalam Merealisasikan Kemudahan Berusaha di Indonesia, Jurnal Rechtsvinding, Volume 6 Nomor 3, (2007).

William Bosworth, "An INTEPRETATION OF Political Argumen," European Journal of Political Theory (2016).

\section{Internet}

Badan Koordinasi Penanaman Modal, "Perbaikan Pelaksanaan Kemudahan Berusaha Ease of Doing Business di Indonesia", BKPM, https:// www.bkpm.go.id/images/uploads/whyinvest_ file/Greenlab_BKPM_Web_2017_Materi_ Download-EoDB_Ind_20171110.pdf (diakses pada 7 Agustus 2018)

MetroTV News, "Mendagri Sebut Putusan MK Hambat Investasi", MetroTV News, http://news. metrotvnews.com/politik/1bV6ejQb-mendagrisebut-putusan-mk-hambat-investasi (diakses 15 Agustus 2018).

World Bank Group, "Doing Business report series World Bank Group", World bank, http://www. doingbusiness.org/en/reports/global-reports/ doing-business-2019, (diakses pada 7 Agustus 2018)

Pratomo, Harwanto Bimo, "5 Keluhan Investor pada Iklim Investasi Indonesia, Salah Satunya Aturan Capai 43.000", Merdeka.com, https://www. merdeka.com/uang/5-keluhan-investor-padaiklim-investasi-indonesia-salah-satunya-aturancapai-43000.html (diakses 16 Agustus 2018)

Putra, Muhammad Amin. "Masalah Pembatalan Perda oleh Mahkamah Konstitusi", Kolom Hukum Online, Hukum Online, http:// www.hukumonline.com/berita/baca / It58fd70f334428/masalah-pembatalan-Perdaoleh-mahkamah-konstitusi-oleh--muhammadamin-putra (diakses 13 Agustus 2018).
Setiaji, Hidayat, "Jokowi dan Obsesinya Pada Ease of Doing Business", CNBC Indonesia, https://www. cnbcindonesia.com/news/201801251744224-2526/jokowi-dan-obsesinya-pada-ease-ofdoing-business (diakses 8 Agustus 2018)

Sholikin, M. Nur. "Penghapusan Kewenangan Pemerintah untuk Membatalkan Perda; Momentum Mengefektifkan Pengawasan Preventif Dan Pelaksanaan Hak Uji Materiil Mahkamah Agung", Jurnal Recht Vinding Online, (12 Mei 2017),http://rechtsvinding. bphn.go.id/jurnal_online/Putusan\%20PUU\%20 Pembatalan\%20Perda.pdf (diakses 8 Agustus 2018).

\section{Peraturan}

Undang-Undang Dasar Negara Republik Indonesia Tahun 1945 (naskah asli)

Konstitusi Republik Indonesia Serikat

Undang-Undang Dasar Sementara Tahun 1950

Undang-Undang Dasar Negara Republik Indonesia Tahun 1945 (amandemen)

Undang-Undang Nomor 18 tahun 1965 tentang Pokok-pokok Pemerintahan Daerah

Undang-Undang Nomor 5 tahun 1974 tentang Pokok-Pokok Pemerintahan di Daerah

Undang-Undang Nomor 22 tahun 1999 tentang Pemerintahan Daerah

Undang-Undang Nomor 32 tahun 2004 tentang Pemerintahan Daerah

Undang-Undang Nomor 23 Tahun 2014 tentang Pemerintahan Daerah

Undang-Undang Nomor No. 48 tahun 2009 tentang Kekuasaan Kehakiman

Undang-Undang Nomor. 14 tahun 1985 sebagaimana telah diubah dengan UU No. 5 tahun 2004 dan UU No. 3 tahun 2009 tentang Mahkamah Agung

Undang-Undang Nomor 12 tahun 2011 tentang Pembentukan Peraturan Perundang-undangan

\section{Putusan Mahkamah Konstitusi}

Putusan Mahkamah Konstitusi No. 137/PUUXIII/2015

Putusan Mahkamah Konstitusi No. 56/PUU-XIV/2016 